\title{
Enhanced Coupling of Neonatal Muscarinic Receptors in Rat Brain to Phosphoinositide Turnover
}

\author{
Anne M. Heacock, Stephen K. Fisher, and Bernard W. Agranoff \\ Neuroscience Laboratory, University of Michigan, Ann Arbor, Michigan, U.S.A.
}

\begin{abstract}
The relationship between the density of the muscarinic receptor in developing rat cerebral cortex and its coupling to phosphoinositide turnover is examined. Tissue slices from rats of various ages were incubated with myo$\left[2-{ }^{3} \mathrm{H}\right]$ inositol, and the effect of carbamoylcholine on the release of total inositol phosphates was determined. Binding of $\left[{ }^{3} \mathrm{H}\right]$ quinuclidinyl benzilate was determined in the same tissue. Although muscarinic receptor density in day- $18 \mathrm{em}-$ bryonic cortex was only $5 \%$ of that in the adult, the maximal response of stimulated phosphoinositide turnover to carbamoylcholine (1-10 mM) was at the adult level (i.e., threefold increase). Comparison of the dependence of the turnover on carbamoylcholine concentration revealed that in neonates, the dose-response curve was shifted to the left,
\end{abstract}

giving a half-maximal effect at concentrations approximately tenfold lower than that in the adult. In addition, the partial muscarinic agonists oxotremorine- 2 and bethanechol were both more efficacious in young rats than in adults. The differences could not be accounted for either by alterations in agonist affinity for the receptor or by the presence of "spare" muscarinic receptors. These results indicate that muscarinic receptors in fetal and newborn rat cerebral cortex are more efficiently coupled to stimulation of phosphoinositide turnover than in the adult. Key Words: Inositol phospholipid-Muscarinic receptors-Rat cerebral cortex development. Heacock A. M. et al. Enhanced coupling of neonatal muscarinic receptors in rat brain to phosphoinositide turnover. $J$. Neurochem. 48, 1904-1911 (1987).
At birth, rat brain muscarinic acetylcholine receptor (mAChR) density is very low ( $10 \%$ of adults), as is the activity of the presynaptic marker choline acetyltransferase (Coyle and Yamamura, 1976; Kuhar et al., 1980). Activation of the $\mathrm{mAChR}$ in adult brain (Hokin and Hokin, 1955) results in the stimulation of the turnover of inositol phospholipids and leads to the formation of the second messengers inositol 1,4,5-trisphosphate $\left(\mathrm{IP}_{3}\right)$ and diacylglycerol (Berridge and Irvine, 1984; Nishizuka, 1984). Little is known about the functional coupling of the $\mathrm{mAChR}$ at early stages in rat brain development, although muscarinic stimulation of phosphoinositide turnover has been observed in 7-day-old cerebral cortex (Reddy and Sastry, 1979; Lee et al., 1985) and in 6-day-old hippocampus (Nicoletti et al., 1986). The developing CNS thus offers a useful model system in which to examine the relationship between $\mathrm{mAChR}$ density and the magnitude of stimulated phosphoinositide turnover. This study was undertaken to determine at which stage of development $\mathrm{mAChRs}$ in fetal and newborn rat cere- bral cortex are coupled to phosphoinositide turnover and to explore the possibility of differences in coupling characteristics during development. The results indicate that mAChRs of 18-day-old embryonic cerebral cortex, the earliest examined, are linked to stimulated inositol lipid hydrolysis. Moreover, although few receptors are present in fetal and neonatal rat brain, they appear to be more efficiently coupled to the phosphoinositide response than are adult $\mathrm{mAChRs}$. A preliminary report of this study has appeared in abstract form (Heacock et al., 1986).

\section{MATERIALS AND METHODS}

Carbamoylcholine (carbachol), bethanechol, atropine, and arterenol (noradrenaline) were purchased from Sigma Chemical Co. (St. Louis, MO, U.S.A.); ibotenic acid was obtained from Regis Chemical Co. (Morton Grove, IL, U.S.A.); $m y o-\left[2-{ }^{3} \mathrm{H}\right]$ inositol $(15 \mathrm{Ci} / \mathrm{mmol})$ was purchased from ARC (St. Louis, MO, U.S.A.); and L- $\left[{ }^{3} \mathrm{H}\right]$ quinuclidinyl benzilate (QNB; $33.1 \mathrm{Ci} / \mathrm{mmol})$ and propylbenzylcholine mustard ( $\operatorname{PrBCM})$ were purchased from New England
Received August 29, 1986; revised manuscript accepted December 8,1986 .

Address correspondence and reprint requests to Dr. A. M. Heacock at Neuroscience Laboratory Building, University of Michigan, 1103 East Huron, Ann Arbor, MI 48104-1687, U.S.A.
Abbreviations used: CCh, carbamoylcholine; IBO, ibotenic acid; $I P_{1}$, inositol 1-phosphate; $I_{3}$, inositol 1,4,5-trisphosphate; IPs, total inositol phosphates; $\mathrm{mAChR}$, muscarinic acetylcholine receptor; NA, norepinephrine; PrBCM, propylbenzylcholine mustard; QNB, quinuclidinyl benzilate. 
Nuclear (Boston, MA, U.S.A.). Dowex-1 $\times 8$ (100-200 mesh; in the formate form) was obtained from BioRad (Rockville Centre, NY, U.S.A.).

\section{Release of labeled inositol phosphates from brain slices}

Wistar rats of the indicated ages were killed by decapitation, the cerebral cortex was dissected, and cross-chopped slices $(350 \times 350 \mu \mathrm{m})$ prepared on a Mcllwain tissue chopper. For the newborn rats, tissue pooled from eight to 12 animals was used for each experiment. Adult (6-10 weeks, male) samples included tissue from one to two animals. A continuous labeling paradigm (Berridge et al., 1982) was carried out essentially as previously described (Fisher and Bartus, 1985). This was chosen, rather than prelabeling, because of its greater sensitivity and decreased handling of the fragile neonatal tissue. Tissue slices were washed five times for a total of $30-45 \mathrm{~min}$ in $10-20 \mathrm{ml}$ of warm buffer $\mathrm{A}$ [ 142 $\mathrm{m} M \mathrm{NaCl} ; 5.6 \mathrm{~m} M \mathrm{KCl} ; 2.2 \mathrm{~m} M \mathrm{CaCl}_{2} ; 3.6 \mathrm{~m} M \mathrm{NaHCO}_{3}$; $1 \mathrm{~m} M \mathrm{MgCl}_{2} ; 5.6 \mathrm{~m} M$ glucose; and $30 \mathrm{~m} M N$-2-hydroxyethylpiperazine- $N^{\prime}$-2-ethanesulfonic acid (HEPES buffer, $\mathrm{pH}$ 7.4)]. Fifty microliter aliquots of tissue slices (0.6-1.1 mg of protein) were incubated for $120 \mathrm{~min}$ at $37^{\circ} \mathrm{C}$ in buffer A, which contained $3 \mu \mathrm{Ci}(0.4 \mu M) m y o-\left[2-{ }^{3} \mathrm{H}\right]$ inositol, 15 $\mathrm{m} M \mathrm{LiCl}$, and the indicated agonists (or buffer $\mathrm{A}$ for controls), in a total volume of $0.5 \mathrm{ml}$ (Berridge et al., 1982). Reactions were terminated by the addition of $1.5 \mathrm{ml}$ of chloroform/methanol (1:2, by vol). The water-soluble total inositol phosphates (IPs) were separated from myo-[2- $\left.{ }^{3} \mathrm{H}\right]$ inositol by ion-exchange chromatography and quantitated as previously described (Fisher et al., 1984). An aliquot of the lower organic phase was removed to determine the incorporation of $m y o-\left[2-{ }^{3} \mathrm{H}\right]$ inositol into phospholipid. Data are expressed as dpm $\left[{ }^{3} \mathrm{H}\right] \mathrm{IPs}$ per $10^{4} \mathrm{dpm}\left[{ }^{3} \mathrm{H}\right]$ inositol lipids. In some experiments, radioactivity in individual IP species was determined following sequential elution of Dowex-1 (formate form) ion-exchange columns (Berridge et al., 1983). For both neonatal and adult rats, most of the radioactivity was in inositol 1-phosphate $\left(\mathrm{IP}_{1}\right)$, as previously noted for guinea pig brain (Fisher and Bartus, 1985), with only $0.3-$ $0.6 \%$ of the radioactivity in $\mathrm{IP}_{3}$. Prior to each experiment, the $m y o-\left[2{ }^{3} \mathrm{H}\right]$ inositol substrate was passed through a similar column to remove possible polar contaminants. Data for stimulated IP release as a function of agonist concentration were analyzed as described previously by means of a computer curve-fitting program (Fisher et al., 1983) that gives the concentration of agonist required for one-half maximal stimulation of IP release $\left(\mathrm{EC}_{50}\right)$. Data are presented as mean \pm SEM. Statistical significance was evaluated by means of the Student's $t$ test.

\section{$\left.{ }^{3} \mathrm{H}\right] \mathrm{QNB}$ binding to brain homogenates}

Homogenates of freshly dissected cerebral cortex were prepared in $10 \mathrm{mM}$ sodium phosphate buffer $(\mathrm{pH} 7.4)$ and $100-400 \mu \mathrm{g}$ of protein incubated in $2 \mathrm{ml}$ of buffer $\mathrm{A}$ at $20^{\circ} \mathrm{C}$ with $1.0 \mathrm{nM} \mathrm{L}-\left[{ }^{3} \mathrm{H}\right] \mathrm{QNB}$. Reactions were terminated after 90 min by vacuum filtration through GF/B filters, and radioactivity was quantitated as previously described (Fisher et al., 1983). Specific binding was calculated by subtraction of radioactivity bound in the presence of $10 \mu M$ atropine. Analysis of $\left[{ }^{3} \mathrm{H}\right] \mathrm{QNB}$ binding to tissue homogenates and its competition by carbachol was performed by a computer curve-fitting program that generates values for concentrations of high- and low-affinity forms of mAChR, with the corresponding affinities $K_{\mathrm{H}}$ and $K_{\mathrm{L}}$, and the percentages of high- and low-affinity sites (McKinney and Coyle, 1982; Fisher et al., 1983). The data were fitted to both a one- and two-site model (i.e., one or two affinity forms of the receptor) and best fit determined by a minimum sum of the squared residuals and a Student's $t$ test on the differences (significance at $\mathrm{p}<0.05$ ). The data were also examined for a systematic deviation from a one- or two-site model by nearest neighbor residual analysis (Birdsall et al., 1978).

Protein was measured by the method of Geiger and Bessman (1972).

\section{Receptor alkylation}

PrBCM, at a concentration of $0.2 \mathrm{~m} M$, was cyclized in 10 $\mathrm{m} M$ sodium phosphate buffer ( $\mathrm{pH} \mathrm{7.4)}$ for $45 \mathrm{~min}$ at room temperature to form the aziridium ion (Young et al., 1972). Brain slices suspended in buffer $A$ were then incubated with PrBCM $\left(2 \times 10^{-9}\right.$ to $\left.2 \times 10^{-8} \mathrm{M}\right)$ at $37^{\circ} \mathrm{C}$ for $15 \mathrm{~min}$. Following extensive washing of the slices with buffer $\mathrm{A}$ at $37^{\circ} \mathrm{C}$ to remove unbound PrBCM, aliquots were either homogenized for determination of QNB binding or incubated with myo- $\left[2-{ }^{3} \mathrm{H}\right]$ inositol, as described above, in the presence or absence of $1 \mathrm{~m} M$ carbachol. Although some recovery from $\mathrm{mAChR}$ inactivation is reported to occur (Young et al., 1972), preliminary studies have established that the degree of receptor occlusion remains constant during the measurement of phosphoinositide turnover (S. K. Fisher, unpublished observations).

\section{RESULTS}

\section{Comparison of $\mathrm{mAChR}$ density and stimulated IP release}

Incorporation of myo-[2- $\left.{ }^{3} \mathrm{H}\right]$ inositol into inositol lipids and basal release of $\left[{ }^{3} \mathrm{H}\right] \mathrm{IPs}$ increased in a linear or nearly linear manner during the $2-\mathrm{h}$ incubation period (data not shown). Initial experiments revealed age-related differences in inositol lipid labeling and a concomitant decline with age of basal release of $\left[{ }^{3} \mathrm{H}\right]$ IPs from $3494 \pm 174 \mathrm{dpm} / \mathrm{mg}$ protein in the neonate to $1,668 \pm 123 \mathrm{dpm} / \mathrm{mg}$ protein in the adult (n $=4, \mathrm{p}<0.05$; see also Nicoletti et al., 1986). Since basal release of $\left[{ }^{3} \mathrm{H}\right] \mathrm{IPs}$ is proportional to the amount of $\left[{ }^{3} \mathrm{H}\right]$ inositol incorporated into lipids, this difference was no longer apparent if the basal values for unstimulated IP release were normalized to lipid labeling: 1day-old cortex $=421 \pm 65$ and adult cortex $=439$ $\pm 112 \mathrm{dpm}\left[{ }^{3} \mathrm{H}\right] \mathrm{IP} / 10^{4} \mathrm{dpm}{ }^{3} \mathrm{H}$-lipid (see also Table 1). Thus, the latter method of calculation offers a more valid means of comparison and was used for all of the data presented here. Cortical tissues from 18day-old embryos, newborn, and adult rats were labeled with $m y o-\left[2-{ }^{3} \mathrm{H}\right]$ inositol, and the ability of carbachol to enhance release of $\left[{ }^{3} \mathrm{H}\right] \mathrm{IPs}$ was assessed (Fig. 1A). Tissue from the same animals was also assayed for $\left[{ }^{3} \mathrm{H}\right] \mathrm{QNB}$ binding (Fig. 1B). The concentration of carbachol necessary to achieve maximal stimulation of IP release varied among the groups of animals from 1 to $10 \mathrm{~m} M$. This stimulation was blocked (75-100\%) by inclusion of atropine $\left(10^{-5} M\right.$; not shown). Examination of the individual IP species revealed the predominant species in stimulated tissue, as under basal conditions, was $\mathrm{IP}_{1}$, whereas only small increases (40- 
TABLE 1. Ontogeny of agonist-stimulated phosphoinositide turnover

\begin{tabular}{lcccr}
\hline & \multicolumn{4}{c}{$\begin{array}{c}\text { Radioactivity in IPs } \\
\left(\mathrm{dpm} / 10^{4} \mathrm{dpm}{ }^{3} \mathrm{H}-\text {-lipid }\right)\end{array}$} \\
\cline { 2 - 5 } Age & Control & CCh & IBO & \multicolumn{1}{c}{ NA } \\
\hline 1 day & $244 \pm 36$ & $1,368 \pm 35$ & $2,398 \pm 158$ & $722 \pm 151$ \\
7 day & $259 \pm 11$ & $2,834 \pm 588$ & $1,742 \pm 333$ & $584 \pm 12$ \\
11 day & $257 \pm 34$ & $2,737 \pm 33$ & $1,879 \pm 249$ & $981 \pm 21$ \\
Adult & $270 \pm 15$ & $1,039 \pm 124$ & $617 \pm 15$ & $1,451 \pm 81$ \\
\hline
\end{tabular}

Slices of cerebral cortex from rats of the indicated ages were incubated with $\left[{ }^{3} \mathrm{H}\right]$ inositol in the absence (control) or presence of one of the following agonists: carbachol $(\mathrm{CCh} ; 10 \mathrm{mM})$, ibotenic acid (IBO; $1 \mathrm{~m} M$ ), or norepinephrine (NA;0.1 $\mathrm{m} M$ ). After $2 \mathrm{~h}$, reactions were terminated by the addition of $1.5 \mathrm{ml}$ chloroform-methanol $(1: 2$, by vol), and radioactivity in the IPs fraction and in inositol lipids was determined as described in Materials and Methods. Basal labeling of ${ }^{3} \mathrm{H}$-lipid (dpm/mg protein) in 1-, 7-, 11 -day-old and adult tissue was $5.7 \times 10^{4}, 4.0 \times 10^{4}, 3.7 \times 10^{4}$, and $2.7 \times 10^{4}$, respectively. Only minimal alterations in lipid labeling were observed on addition of agonist. Values shown are means $( \pm$ SEM) of triplicate samples from one of two similar experiments.

$50 \%)$ in $\left[{ }^{3} \mathrm{H}\right] \mathrm{IP}{ }_{3}$ release in response to carbachol were observed.

Although $\mathrm{mAChR}$ density showed a progressive increase during development, reaching adult levels by 6

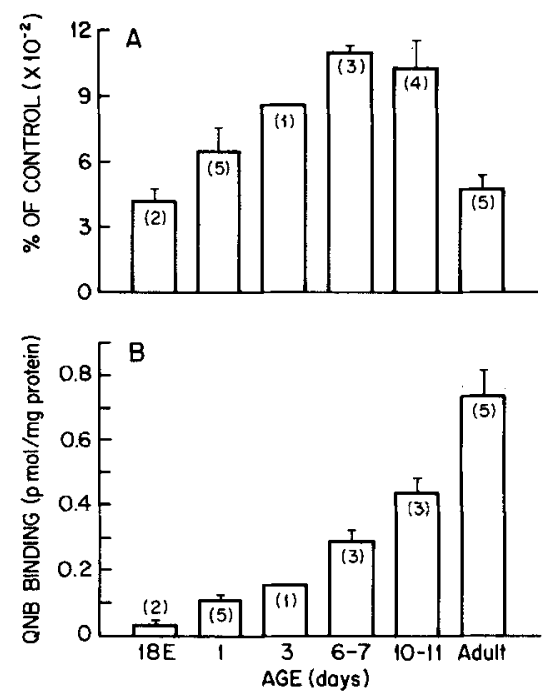

FIG. 1. Developmental changes in carbachol-stimulated $\left[{ }^{3} \mathrm{H}\right] \mathrm{IP}$ release (A) and $\mathrm{mAChR}$ concentration (B) in rat cerebral cortex. $A$ : Tissue slices from 18-day-old embryos (18E), newborn (1-11 days postnatal), and adult rats were incubated in triplicate with $3 \mu \mathrm{Ci}\left[{ }^{3} \mathrm{H}\right]$ inositol and $15 \mathrm{mM} \mathrm{LiCl}$ in the presence of $0-10 \mathrm{mM}$ carbachol. Reactions were terminated after $2 \mathrm{~h}$, and radioactivity in the IP fraction and in inositol lipids was determined. Data are calculated as dpm $\left[{ }^{3} \mathrm{H}\right] \mathrm{IP} / 10^{4} \mathrm{dpm}{ }^{3} \mathrm{H}$-lipid and are expressed as percent of control $\left(\times 10^{-2}\right)$. Values at 6-11 days were significantly different from adult $(p<0.01)$, whereas values at 1 day were not. B: Binding of $\left[{ }^{3} \mathrm{H}\right] \mathrm{QNB}$ to tissue homogenates (100-400 $\mu \mathrm{g}$ protein) was determined by a filtration assay following incubation with $1 \mathrm{nM}\left[{ }^{3} \mathrm{H}\right] \mathrm{QNB}$ for $90 \mathrm{~min}$ in the presence or absence of $10 \mu \mathrm{M}$ atropine. Values shown are mean \pm SEM (or range, for $n=2$ ) for the number of experiments indicated.

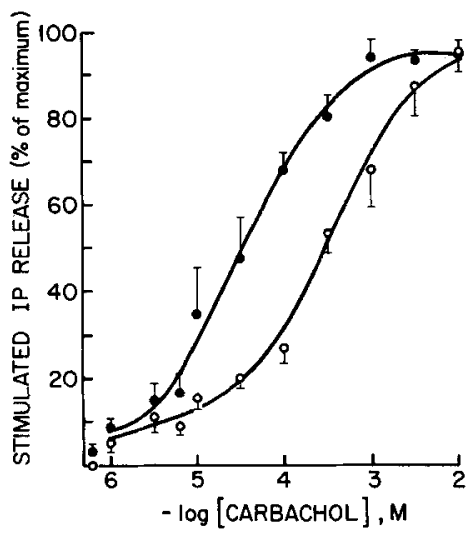

FIG. 2. Dose-response curves for stimulated release of IPS in 1day-oid $(\bullet)$ and adult $(O)$ rat cortex. Tissue slices were incubated with $3 \mu \mathrm{Ci}$ myo- $\left[2-{ }^{3} \mathrm{H}\right]$ inositol in the presence of the indicated concentrations of carbachol. Reactions were terminated after 120 $\mathrm{min}$, and radioactivity in the IPs fraction was determined. Data are expressed as a percentage of the maximum response (shown in Fig. 1). Each value is the mean \pm SEM of four individual experiments. Analysis of the data by a computer curve-fitting program showed a one-site interaction at both ages, although the Hill coefficients were somewhat less than $1,0.66$, and 0.68 for 1 -dayold and adult tissue, respectively.

weeks of age, an "adult" $\left[{ }^{3} \mathrm{H}\right] \mathrm{IP}$ response to carbachol (three- to fourfold increase) was present in the youngest animals examined, 18-day-old embryos, a time when $\left[{ }^{3} \mathrm{H}\right] \mathrm{QNB}$ binding was $<5 \%$ of adult values. The magnitude of the carbachol response continued to increase, reaching twice that of the adult response at 611 days postnatal. Addition of carbachol led to small increases in inositol lipid labeling in 1-day-old cortex but not in adult cortex, $125 \pm 4 \%$ and $100 \pm 4 \%$ of control, respectively (mean \pm SEM for five to eight separate experiments). Thus, if $\left[{ }^{3} \mathrm{H}\right] \mathrm{IP}$ release had been normalized to protein content, carbachol-stimulated release in the newborn would have appeared to be even greater than the fourfold increase (Fig. 1) calculated by normalizing to lipid labeling.

\section{Dose-response for carbachol and effect of partial muscarinic agonists}

Comparison of the carbachol concentration curves for 1-day-old rat cortex and adult rat (6-10 weeks) cortex (Fig. 2) revealed that in the newborn animals, the dose-response curve was shifted to the left, with an $\mathrm{EC}_{50}$ (mean $\pm \mathrm{SEM}$ ) of $39 \pm 8 \mu M$, compared with the adult value of $345 \pm 115 \mu M(p<0.05)$. Comparably low $\mathrm{EC}_{50}$ values were also found in 18-day-old embryonic and 3-day-old postnatal cortex (Fig. 3A), whereas the shift toward adult values appeared to begin at 6 days and be completed by 10 days postnatal. The changes in $\mathrm{EC}_{50}$ were accompanied by alterations in the responses to the partial muscarinic agonists oxotremorine-2 and bethanechol (Fig. 3B and C), both of which were more efficacious in the young rats than in the adults. 

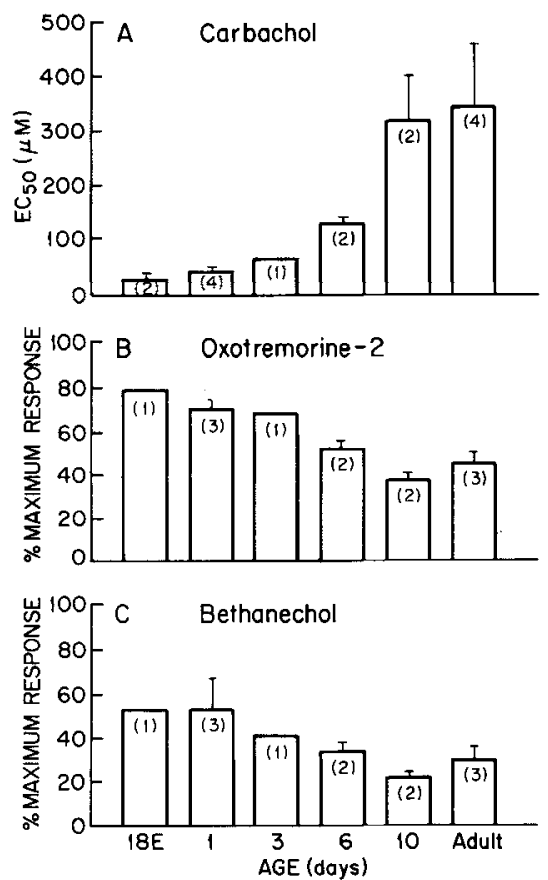

FIG. 3. Developmental changes in the $E C_{50}$ for stimulation of IP release by carbachol (A) and the efficacy of the partial agonists oxotremorine-2 (B) and bethanechol (C). A: Determination of the $\mathrm{EC}_{50}$ for carbachol was carried out as described in Fig. 2 for cerebral cortical tissue from rats of the indicated ages. The mean $E_{50}$ for 1-day-old cortex was significantly different from adult cortex $(p<0.05)$. The $E C_{50}$ was calculated by a computer curve-fitting program. $B$ and $C$ : Tissue slices from rats of the indicated ages were incubated with myo- $\left[2-{ }^{3} \mathrm{H}\right]$ inositol in the presence of optimal concentrations of the partial muscarinic agonists oxotremorine-2 $(1 \mathrm{mM})$ or bethanechol $(30 \mathrm{mM})$. Reactions were terminated after $2 \mathrm{~h}$, and radioactivity in inositol phosphates was determined. $\mathrm{Re}$ sults are expressed as a percentage of the maximum response obtained with carbachol (1-10 $\mathrm{mM})$. Values shown are means \pm SEM (or range, for $n=2$ ) of the indicated number of experiments. Differences between 1-day-old and adult cortex were not statistically significant for bethanechol but were for oxotremorine$2(p<0.002)$. (For structure of oxotremorine-2, see Fisher et al., 1984.)

\section{Carbachol displacement of $\left[{ }^{3} \mathrm{H}\right] \mathrm{QNB}$ binding}

The possibility that the low $\mathrm{EC}_{50}$ for stimulated IP release by carbachol in newborns is accounted for by a higher affinity of the newborn $\mathrm{MAChR}$ for binding of carbachol was assessed by determining the ability of carbachol to displace $\left[{ }^{3} \mathrm{H}\right] \mathrm{QNB}$ from homogenates of 1-day-old or adult rat cortex (Fig. 4). The percentage of high-affinity sites and the $K_{\mathrm{L}}$ values for the two groups did not differ; however, the $K_{\mathrm{H}}$ for 1-day-old cortex appeared to be greater than that for the adult animals $(p<0.05)$. Thus, the differences in carbachol $\mathrm{EC}_{50}$ for stimulated phosphoinositide turnover seem not to reflect altered agonist affinities for the $\mathrm{mAChR}$.

\section{Effect of alkylation of neonatal $\mathrm{mAChRs}$}

The apparent shift in $\mathrm{EC}_{50}$, as well as the efficacy of partial agonists in neonatal cortex, could be interpreted to indicate the presence of "spare" receptors for the phosphoinositide response. This possibility was explored by partial alkylation of mAChRs in 1day-old rat cortex with PrBCM and subsequent comparison of the residual $\mathrm{mAChR}$ density with the ability of carbachol to stimulate [ $\left.{ }^{3} \mathrm{H}\right] \mathrm{IP}$ release (Fig. 5). $\left[{ }^{3} \mathrm{H}\right] \mathrm{QNB}$ binding declined in parallel with the IP response $(r=0.91)$. Intersection with the ordinate above the origin might indicate that some of the mAChRs in the slice preparation are not accessible to carbachol during phosphoinositide turnover measurement, as has been suggested for $\alpha_{1}$-adrenergic receptors during the norepinephrine-stimulated inositol lipid hydrolysis in rat cerebral cortex slices (Johnson and Minneman, 1985).

\section{Comparison with other agonists}

To assess whether the magnitude of carbachol-stimulated IP release in neonatal tissue might be due to a general hypersensitivity of phosphoinositide turnover to receptor activation, the effects of norepinephrine and the glutamate analog, ibotenic acid, were determined and compared with those of carbachol (Table 1). Each displayed a unique developmental profile. In contrast to the equivalent stimulation of IP release in newborns and adults by carbachol, the efficacy of ibotenate showed a substantial decline with age, whereas that of norepinephrine increased.

\section{DISCUSSION}

Evidence is accumulating in support of a major role for inositol lipid breakdown in receptor-mediated transmembrane signaling in the CNS (Berridge and Irvine, 1984; Nishizuka, 1984). mAChR-mediated stimulation of phosphoinositide turnover has been characterized both biochemically and pharmacologically (Fisher and Agranoff, 1985; Fisher, 1986). The $\mathrm{mAChR}$ is proposed to exist in at least two interconvertible forms of high and low affinities (Birdsall et al., 1978). In the CNS, mAChRs appear to be tightly coupled to phosphoinositide turnover in that there is a close relationship between receptor occupancy and stimulated inositol lipid hydrolysis (Fisher, 1986).

In fetal and neonatal rat brain, low levels of $\mathrm{mAChR}$ are present before cholinergic innervation occurs (Coyle and Yamamura, 1976; Kuhar et al., 1980), a time when one might predict little need for the receptors to be functionally coupled to a transmembrane signaling pathway. Contrary to this expectation, activation of the few receptors present in developing rat cerebral cortex elicited as large an increase in phosphoinositide turnover as is observed in the adult (Fig. 1). Calculated as ratios of carbachol-stimulated IP release to $\mathrm{mAChR}$ density, the responses of 18 -dayold embryonic and 1-day-old postnatal rats are, respectively, 20- and 10-fold greater than that in adult brain. Studies of $\mathrm{mAChR}$ function in embryonic chick heart (Orellana and Brown, 1985) and retina (Large et al., 1985a) have similarly revealed coupling of the receptors to phosphoinositide turnover prior to 
FIG. 4. Occupancy of $m A C h R$ in 1-day-old (A) and adult (B) rat cerebral cortex by carbachol. Aliquots of homogenates of cerebral cortex (100-400 $\mu \mathrm{g}$ protein) were incubated with L$(-)\left[^{3} \mathrm{H}\right]$ QNB $(1.0 \mathrm{nM}$ in $\mathrm{A} ; 1.13 \mathrm{nM}$ in $\mathrm{B})$ in the presence of various concentrations of carbachol. The displacement of $\left[{ }^{3} \mathrm{H}\right] \mathrm{QNB}$ binding was analyzed for a one- or two-site interaction by a computer program that generated plots of theoretical one-site $(O)$ and two-site $(\bullet)$ fits. These are compared to the actual $(\Delta)$ receptor occupancy data. Similar affinity constants for $\left[{ }^{3} \mathrm{H}\right] \mathrm{QNB}\left(K_{\mathrm{Q}}\right), 78$ and $86 \mathrm{pM}$, were obtained for 1-day-old and adult cortex. Carbachol binding to mAChR in both tissues fit the criteria for a twosite model (see Materials and Methods). Results shown are from one of four separate experiments that gave similar results. Mean values for $K_{\mathrm{H}}, K_{\mathrm{L}}$, and percent high-affinity sites ( \pm SEM) were $4.2 \pm 1.3 \mu M, 212 \pm 19 \mu M$, and $28 \pm 4 \%$ for 1-day-old cortex, and $0.8 \pm 3 \mu M, 250 \pm 51$ $\mu M$, and $24 \pm 3 \%$ for adult cortex; $K_{H}$ for 1 -dayold cortex was significantly different from that of the adult cortex $(p<0.05)$.

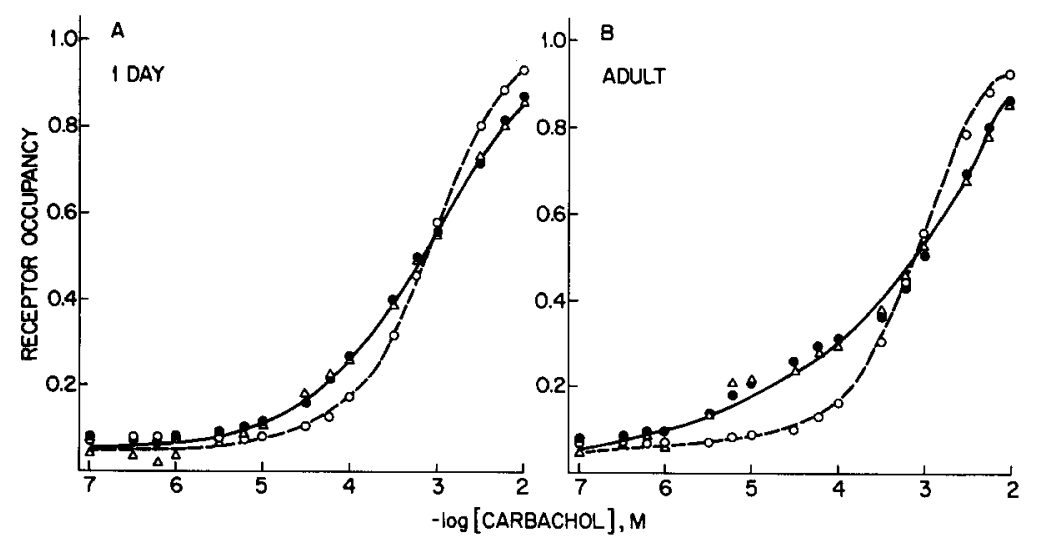

innervation. In avian heart, the ability of carbachol to stimulate IP release appears to decline with age (Orellana and Brown, 1985).

A further difference in the coupling characteristics of neonatal and adult $\mathrm{mAChRs}$ was revealed by examination of the carbachol dose-response curves (Fig. 2). The concentration of carbachol required to elicit a half-maximal phosphoinositide response was approximately tenfold lower in newborns than in adults. This observation might be accounted for by alterations in the binding of the agonist to the two affinity forms of the mAChR. Although there is a report that the highaffinity site is absent from 1-day-old rat cortex (Kuhar

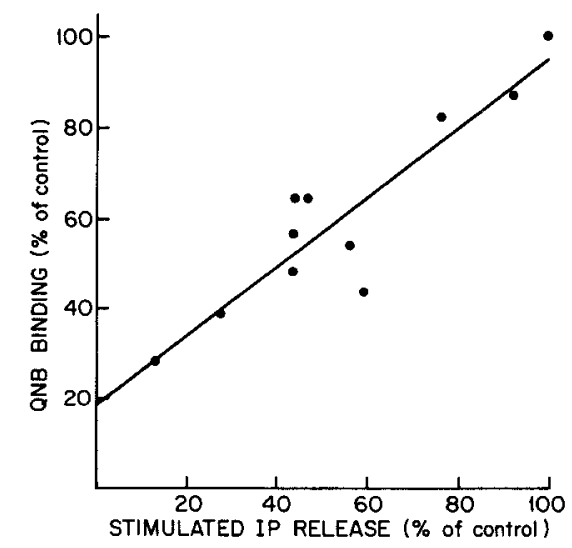

FIG. 5. Correlation of $\mathrm{mAChR}$ receptor density with carbacholstimulated IP release. Slices of cerebral cortex from 1-day-old rats were alkylated with various concentrations of $\operatorname{PrBCM}\left(2 \times 10^{-9}\right.$ to $2 \times 10^{-8} M$ ), as described in Materials and Methods. Following washing of the tissue slices, residual $\left[{ }^{3} \mathrm{H}\right]$ QNB binding and the ability of carbachol ( $1 \mathrm{mM})$ to stimulate IP release was assessed. There was a significant correlation $(r=0.91, p<0.01)$ between receptor loss and loss of stimulated IP release. Results were obtained from three separate experiments. et al., 1980), we found that 1-day-old and adult rat cortex contained a similar proportion of high-affinity sites. In addition, there was no enhancement of agonist binding affinity for either high- or low-affinity sites in 1-day-old tissue. Indeed, there appears to be a reduced carbachol affinity for the high-affinity sites in 1-day-old cortex (Fig. 4), a finding similar to that reported for the developing avian retina (Large et al., $1985 a$ ). It remains possible that affinity constants obtained from tissue homogenates do not accurately reflect agonist affinities of intact tissue slices, although comparisons of intact and homogenized N1E-115 neuroblastoma cells revealed no difference in muscarinic agonist binding parameters (McKinney et al., 1985). Precise comparisons between the agonist affinity constants and the carbachol $\mathrm{EC}_{50}$ for phosphoinositide turnover are not possible, since the binding assays were carried out at $20^{\circ} \mathrm{C}$ in the absence of $\mathrm{Li}^{+}$, whereas the IP release assays were carried out at $37^{\circ} \mathrm{C}$ in the presence of $\mathrm{Li}^{+}$; however, inclusion of 15 $\mathrm{m} M \mathrm{LiCl}$ in the QNB assay did not alter the binding characteristics of either newborn or adult cortical tissue (data not shown). Decreasing temperature reportedly results in small decreases in the binding constants for the mAChR in neuroblastoma N1E-1 15 cells (McKinney et al., 1985). Thus, differential temperature effects on neonatal and adult $\mathrm{mAChR}$ binding characteristics cannot be ruled out, although they would not likely be of sufficient magnitude to affect the conclusion that differences in the affinity of the $\mathrm{mAChR}$ for carbachol do not account for differences in the $\mathrm{EC}_{50}$ for phosphoinositide turnover.

The absence of marked changes in the affinity of the mAChR for carbachol in tissue exhibiting an enhanced agonist efficacy for phosphoinositide turnover might indicate the presence of spare receptors, i.e., submaximal receptor occupancy required for maxi- 
mal response. The greater efficacy of the partial muscarinic agonists oxotremorine-2 and bethanechol (Fig. 3) is also consistent with this possibility. As observed for adult brain (Fisher and Snider, 1986), irreversible inactivation of the $\mathrm{mAChR}$ by alkylation with PrBCM results in a parallel loss of receptor number and carbachol-stimulated IP release (Fig. 5). Thus, in neonatal as in adult brain, there is little evidence of $\mathrm{mAChR}$ reserve for inositol lipid hydrolysis.

The developmental profile of carbachol-stimulated phosphoinositide turnover in rat cerebral cortex contrasts markedly with that of two other phosphoinositide-linked agonists examined. In agreement with the observations of Schoepp and Rutledge (1985) and Nicoletti et al. (1986), we find that the response to norepinephrine increases during development, whereas that of the glutamate analog, ibotenic acid, decreases (Table 1). Nicoletti et al. (1986) also find a robust phosphoinositide response elicited by addition of carbachol to 6-day-old rat hippocampus, with no substantial change during development. Comparison with these other agonists may prove useful in elucidating the mechanism of the observed enhanced coupling of fetal and neonatal mAChRs. For example, there is indirect evidence indicating that guanine nucleotide-binding regulatory proteins (G-proteins) play a role in receptor coupling to phosphoinositide turnover (Gonzales and Crews, 1985; Joseph, 1985; Litosch et al., 1985). G-proteins have been found to interact with the $\mathrm{mAChR}$ (Florio and Sternweiss, 1985 ) and with $\alpha_{1}$-adrenergic receptors (Goodhart et al., 1982) and guanine nucleotides alter the binding of agonists to the mAChR (Ehlert et al., 1981). It has been suggested that a lack of such a regulatory protein might account for the limited coupling of $\alpha_{1}$-adrenergic receptors to inositol lipid turnover in 7- and 14day-old rat cortex (Schoepp and Rutledge, 1985). Similarly, the progressive reduction in the ability of glutamate and ibotenic acid to stimulate IP release in developing rat hippocampus (Nicoletti et al., 1986) may reflect the appearance of a negative or inhibitory coupling factor. The results described here for the $\mathrm{mAChR}$ could indicate the presence of a positive coupler early in development, which subsequently declines. Alternatively, there may be a negative coupler that appears later in development and serves to diminish the signal produced by the increased numbers of mAChRs. Precedent for such a mechanism can be found in recent studies in which alterations in the coupling of heart $\alpha_{1}$-adrenergic receptors to contraction, on the one hand (Steinberg et al., 1985), and the coupling of heart mAChRs to adenylate cyclase inhibition (Liang et al., 1986), on the other, could each be correlated with increased amounts of G-proteins. It may be that the greater sensitivity to muscarinic agonists in fetal and neonatal cortex constitutes a compensatory mechanism for the relatively low levels of acetylcholine encountered by the receptor at this stage of development (Coyle and Yamamura, 1976). It should be noted, however, that the shift to adult $\mathrm{EC}_{50}$ values observed in the present study does not correspond closely to the developmental increase in cholinergic input to the cortex: At 10 days postnatal, the $\mathrm{EC}_{50}$ for carbachol stimulation of inositol lipid hydrolysis did not differ from the adult value, whereas cortical choline acetyltransferase activity is reportedly only $10 \%$ of that in the adult at this time (Coyle and Yamamura, 1976).

Relevant factors that might account for the enhanced coupling of the $\mathrm{mAChR}$ to phosphoinositide turnover, other than the postulated changes in regulatory proteins, include possible structural alterations in the mAChR or in its environment that might alter its coupling characteristics, e.g., changes in membrane fluidity (Rauch and Hitzemann, 1986) or in the anatomical localization of the receptor. Differences in the molecular weight and isoelectric point of the $\mathrm{mAChR}$ during development have been found in embryonic chick retina and rat olfactory bulb (Large et al., $1985 a, b, 1986)$. Alternatively, the pool of inositol phospholipid coupled to the MAChR might be preferentially labeled with $\left[{ }^{3} \mathrm{H}\right]$ inositol in neonatal brain, thus giving rise to an increased specific activity of released inositol phosphates. Data on the concentrations of the phosphoinositides in developing brain have recently been reviewed by Sun and Foudin (1985). In addition, it is likely that a common biochemical mechanism of mAChR-stimulated phosphoinositide turnover is shared by neonatal and adult cortex, i.e., phosphodiesteratic cleavage of phosphatidylinositol 4,5-bisphosphate with subsequent dephosphorylation of $\mathrm{IP}_{3}$ and accumulation of $\mathrm{IP}_{1}$ in the presence of $\mathrm{Li}^{+}$(Berridge, 1983; Berridge et al., 1983; Downes and Wusteman, 1983; Fisher et al., 1984); however, this mechanism has not been firmly established in brain (Hawthorne, 1986), and given the predominant release of $\mathrm{IP}_{1}$ in both newborn and adult tissues, it remains possible that a secondary breakdown of phosphatidylinositol occurs in response to increased intracellular $\mathrm{Ca}^{2+}$ (Wilson et al., 1985).

Differences in both the affinity and efficacy with which muscarinic agonists enhance phosphoinositide turnover could well have broad significance in the understanding of higher brain function. Such differences have been reported previously in both neural and nonneural tissues (Brown and Brown, 1984; Ek and Nahorski, 1986; Evans et al., 1985; Fisher et al., 1983, 1984; Fisher and Bartus, 1985; Gil and Wolfe, 1985; Jacobson et al., 1985). The developing rat brain provides a longitudinal model that lends itself particularly well to tackling the problem of how $\mathrm{mAChR}$ coupling to second messengers is regulated.

Acknowledgment: We thank Stephanie McWethy for excellent secretarial assistance. This work was supported by NIH grants NS 15413 (B.W.A.) and NS 23831 (S.K.F.). 


\section{REFERENCES}

Berridge M. J. (1983) Rapid accumulation of inositol trisphosphate reveals that agonists hydrolyze polyphosphoinositides instead of phosphatidylinositol. Biochem. J. 212, 849-858.

Berridge M. J. and Irvine R. F. (1984) Inositol trisphosphate, a novel second messenger in cellular signal transduction. Nature $312,315-321$.

Berridge M. J., Downes C. P., and Hanley M. R. (1982) Lithium amplifies agonist-dependent phosphatidylinositol responses in brain and salivary glands. Biochem. J. 206, 587-595.

Berridge M. J., Dawson R. M. C., Downes C. P., Heslop J. P., and Irvine, R. F. (1983) Changes in the levels of inositol phosphates after agonist-dependent hydrolysis of membrane phosphoinositides. Biochem. J. 212, 473-482.

Birdsall N. J. M., Burgen A. S. V., and Hulme E. C. (1978) The binding of agonists to brain muscarinic receptors. Mol. Pharmacol. 14, 723-726.

Brown J. H. and Brown S. L. (1984) Agonists differentiate muscarinic receptors that inhibit cyclic AMP formation from those that stimulate phosphoinositide metabolism. J. Biol. Chem. 259, 3777-3781.

Coyle J. T. and Yamamura H. I. (1976) Neurochemical aspects of the ontogenesis of cholinergic neurons in the rat brain. Brain Res. 118, 429-440.

Downes C. P. and Wusteman W. M. (1983) Breakdown of polyphosphoinositides and not phosphatidylinositol accounts for muscarinic agonist stimulated inositol phospholipid metabolism in rat parotid glands. Biochem. J. 216, 633-640.

Ehlert F. J., Roeske W. R., and Yamamura H. I. (1981) Muscarinic receptor: Regulation by guanine nucleotides, ions and $\mathrm{N}$-ethylmaleimide. Fed. Proc. 40, 153-159.

Ek B. and Nahorski S. R. (1986) Muscarinic receptor mediated inositol phospholipid metabolism in guinea-pig parotid gland, ileum and cortex. Trends Pharmacol. Sci. Suppl.: Subtypes of Muscarinic Receptors II, 84

Evans T., Hepler J. R., Masters S. B., Brown J. H., and Harden T. K. (1985) Guanine nucleotide regulation of agonist binding to muscarinic cholinergic receptors. Biochem. J. 232, 751-757.

Fisher S. K. (1986) Inositol lipids and signal transduction at CNS muscarinic receptors. Trends Pharmacol. Sci. Suppl.: Subtypes of Muscarinic Receptors II, 61-65.

Fisher S. K. and Agranoff B. W. (1985) The biochemical basis and functional significance of enhanced phosphatidate and phosphoinositide turnover, in Phospholipids in Nervous Tissues (Eichberg J., ed), pp. 241-295. John Wiley, New York.

Fisher S. K. and Bartus R. T. (1985) Regional differences in the coupling of muscarinic receptors to inositol phospholipid hydrolysis in guinea pig brain. J. Neurochem. 45, 1085-1095.

Fisher S. K. and Snider R. M. (1986) Receptor occupancy requirements for muscarinic receptor-stimulated phosphoinositide turnover in brain and in neuroblastoma. (Abstr.) Soc. Neurosci. Abstr. 12, 491.

Fisher S. K., Klinger P. D., and Agranoff B. W. (1983) Muscarinic agonist binding and phospholipid turnover in brain. J. Biol. Chem. 258, 7358-7363.

Fisher S. K., Figueiredo J. C., and Bartus R. T. (1984) Differential stimulation of inositol phospholipid turnover in brain by analogs of oxotremorine. J. Neurochem. 43, 1171-1179.

Florio V. A. and Sternweiss P. C. (1985) Reconstitution of resolved muscarinic cholinergic receptors with purified GTP-binding proteins. J. Biol. Chem. 260, 3477-3483.

Geiger P. J. and Bessman S. P. (1972) Protein determination by Lowry's method in the presence of sulfhydryl reagents. Anal. Biochem. 49, 467-473.

Gil D. W. and Wolfe B. B. (1985) Pirenzepine distinguishes between muscarinic receptor-mediated phosphoinositide breakdown and inhibition of adenylate cyclase. J. Pharmacol. Exp. Ther. 232, 608-616.

Gonzales R. A. and Crews F. T. (1985) Guanine nucleotides stimu- late production of inositol trisphosphate in rat cortical membranes. Biochem. J. 232, 799-804.

Goodhardt M., Ferry N., Geynet P., and Hanoune J. (1982) Hepatic $\alpha_{1}$-adrenergic receptors show agonist-specific regulation by guanine nucleotides. J. Biol. Chem. 257, 11577-11583.

Hawthorne J. N. (1986) Does receptor-linked phosphoinositide metabolism provide messengers mobilizing calcium in nervous tissue? Int, Rev. Neurobiol. 28, 241-273.

Heacock A. M., Fisher S. K., and Agranoff B. W. (1986) Developmental aspects of muscarinic receptor coupling to polyphosphoinositide turnover in rat cortex. (Abstr.) Soc. Neurosci. Abstr. 12, 491.

Hokin L. E. and Hokin M. R. (1955) Effects of acetylcholine on the turnover of phosphoryl units in individual phospholipids of pancreas slices and brain cortex slices. Biochim. Biophys. Acta $18,102-110$.

Jacobson M. D., Wusteman M., and Downes C. P. (1985) Muscarinic receptors and hydrolysis of inositol phospholipids in rat cerebral cortex and parotid gland. J. Neurochem. 44, 465-472.

Johnson R. D. and Minneman K. P. (1985) $\alpha_{1}$-Adrenergic receptors and stimulation of $\left[{ }^{3} \mathrm{H}\right]$ inositol metabolism in rat brain: Regional distribution and parallel inactivation. Brain Res. 341, 7-15.

Joseph S. K. (1985) Receptor-stimulated phosphoinositide metabolism: A role for GTP-binding proteins? Trends Biochem. Sci. 10, 297-298.

Kuhar M. J., Birdsall N. J. M., Burgen A. S. V., and Hulme E. C. (1980) Ontogeny of muscarinic receptors in rat brain. Brain Res. 184, 375-383.

Large T. H., Cho N. J., De Mello F. G., and Klein W. L. (1985a) Molecular alteration of a muscarinic acetylcholine receptor system during synaptogenesis. J. Biol. Chem. 260, 8873-8881.

Large T. H., Rauh J. J., De Mello F. G., and Klein W. L. (1985b) Two molecular weight forms of muscarinic acetylcholine receptors in the avian central nervous system: Switch in predominant form during differentiation of synapses. Proc. Natl. Acad. Sci. USA 82, 8785-8789.

Large T. H., Lambert M. P., Gremillion M. A., and Klein W. L. (1986) Parallel postnatal development of choline acetyltransferase activity and muscarinic acetylcholine receptors in the rat olfactory bulb. $J$. Neurochem . 46, 671-680.

Lee W., Nicklaus K. J., Manning D. R., and Wolfe B. B. (1985) Ontogeny of muscarinic receptor binding sites and muscarinic receptor-mediated stimulation of phosphoinositide breakdown and inhibition of cyclic AMP accumulation in rat forebrain. Soc. Neurosci. Abstr. 11, 95.

Liang B. T., Hellmich M. R., Neer E. J., and Galper J. B. (1986) Development of muscarinic cholinergic inhibition of adenylate cyclase in embryonic chick heart. J. Biol. Chem. 261, 9011 9021.

Litosch I., Wallis C., and Fain J. N. (1985) 5-Hydroxytryptamine stimulates inositol phosphate production in a cell-free system from blowfly salivary glands. J. Biol. Chem. 260, 5464-5471.

McKinney M. and Coyle J. T. (1982) Regulation of neocortical muscarinic receptors: Effects of drug treatment and lesions. $J$. Neurosci. 2, 97-105.

McKinney M., Stenstrom C., and Richelson E. (1985) Muscarinic responses and binding in a murine neuroblastoma clone (NIE115). Mediation of separate responses by high affinity and low affinity agonist-receptor conformations. Mol. Pharmacol. 27, 223-235.

Nicoletti F., ladarola M. J., Wroblewski J. T., and Costa E. (1986) Excitatory amino acid recognition sites coupled with inositol phospholipid metabolism: Developmental changes and interaction with $\alpha_{1}$-adrenoceptors. Proc. Natl. Acad. Sci. USA 83, 1931-1935.

Nishizuka Y. (1984) Turnover of inositol phospholipids and signal transduction. Science 225, 1365-1370.

Orellana S. A. and Brown J. H. (1985) Stimulation of phosphoinositide hydrolysis and inhibition of cyclic AMP formation by 
muscarinic agonists in developing chick heart. Biochem. Pharmacol. 34, 1321-1324.

Rauch S. L. and Hitzemann R. J. (1986) Developmental changes in synaptic membrane order: A comparison of regions in the rat brain. Dev. Brain Res. 26, 221-227.

Reddy P. V. and Sastry P. S. (1979) Studies on neurotransmitterstimulated phospholipid metabolism with cerebral tissue suspensions: A possible biochemical correlate of synaptogenesis in normal and undernourished rats. Brain Res. 168, 287-298.

Schoepp D. D. and Rutledge C. O. (1985) Comparison of postnatal changes in alpha $a_{1}$-adrenoceptor binding and adrenergic stimulation of phosphoinositide hydrolysis in rat cerebral cortex. Biochem. Pharmacol. 34, 2705-2711.
Steinberg S. F., Drugge E. D., Bilezikian J. P., and Robinson R. B. (1985) Acquisition by innervated cardiac myocytes of a pertussis toxin-specific regulatory protein linked to the $\alpha_{1}$-receptor. Science 230, 186-188.

Sun G. Y. and Foudin L. L. (1985) Phospholipid composition and metabolism in the developing and aging nervous system, in Phospholipids in Nervous Tissue (Eichberg J., ed), pp. 79-134. John Wiley, New York.

Wilson D. B., Neufeld E. J., and Majerus P. W. (1985) Phosphoinositide interconversion in thrombin-stimulated human platelets. J. Biol. Chem. 260, 1046-1051.

Young J. M., Hiley R., and Burgen A. S. V. (1972) Homologues of benzilylcholine mustard. J. Pharm. Pharmacol. 24, 950-954. 